\title{
Internationalisation of higher education for pluriversity: a decolonial reflection
}

\author{
Sabelo J. Ndlovu-Gatsheni
}

Abstract: At the centre of the debates on internationalisation one can notice tensions between the agenda of completing the incomplete project of modernity, which dovetails into the current hegemonic neoliberal capitalist globalisation with its 'global turn' towards the creation of 'global' universities; and the resurgent and insurgent agenda of completing the incomplete project of decolonisation predicated on deracialisation, de-hierarchisation, decorporatisation, and depatriachisation of knowledge and education. This article contributes to the decolonisation of internationalisation of higher education at four main levels. In the first place, it underscores the primacy of knowledge in creating a reality known as 'the international' with Europe and North America at the centre. In the second, it makes a strong case for taking seriously the idea of the locus of enunciation of knowledge as a basis of critique of the hegemonic neoliberal globalisation's notion of a global economy of knowledge that is decontextualised and ignores the resilient uneven division of intellectual and academic labour. In the third, it calls for intercultural translation, mosaic/convivial epistemology, and ecologies of knowledges as key to any successful decolonised internationalisation of higher education. In the fourth, it argues for the reconstruction of university into pluriversity informed by the practices of globalectics and the coexistence of particularities. These four interventions constitute essential enablers in the cultivation of transnational knowledge that is of service to a world characterised by planetary human entanglements.

Keywords: Ecologies of knowledges, decolonisation, Eurocentrism, higher education, mosaic epistemology, pluriversality. 


\section{Introduction}

How did Europe universalize its particularities, particularized other people's universalities, and made itself normative to others' abnormativity?

Hamid Dabashi (2019: 52)

I believe that we live in a very exciting era in the world of knowledge, precisely because we are living in a systemic crisis that is forcing us to reopen the basic epistemological questions and look to structural reorganization of the world of knowledge.

Immanuel Wallerstein (2004: 58)

This article intervenes on the subject of the internationalisation of higher education at four levels. At the first level of analysis, it introduces a decolonial approach which challenges the colonial vertical conceptions of internationalisation of higher education where 'the international' is Europe and North America. It proposes a horizontal non-colonial internationalisation of higher education which is underpinned by ecologies of knowledges and pluriversities rather than universities. 'Pluri' captures diversity while 'uni' means one. At the second level, it brings to the fore the concept of a locus of enunciation as it underscores the importance of the 'local' in the 'international' and as it critiques the present hegemonic neoliberal capitalist-driven globalisation and the notions of a global economy of knowledge, which is assumed to be decontextualised and universal. At a third level, the article highlights the necessity of the concepts of intercultural translation of knowledge, mosaic epistemology/epistemology of conviviality, and ecologies of knowledges as key anchors for a decolonised international higher education. The last part reiterates the importance of a decolonised pluriversal higher education freed from instrumental market-informed imperatives of commercialisation, commodification of knowledge, and profit accumulation.

What is posited here is that there is no genuinely international higher education without decolonisation of knowledge and education. Decolonisation confronts epistemicides, cognitive injustices, and hierarchies in knowledge and education as its key contribution to the internationalisation of higher education and cultivation of knowledge that fully recognises planetary human entanglements. Achille Mbembe (2019: 17) provided a useful definition of decolonisation as it relates to the internationalisation of higher education: 'bringing as equitably as possible everybody, every person and every text, every archive and every memory in the sphere of care and concern. It has to do with proximity as opposed to insulation, with the invention in-common of a shared inside, a shared roof and a shared shelter.'

This forms the departure point for this article and what is distinctive about this article is that it does not embrace the neoliberal bourgeois neo-Habermasian ideas of completing the incomplete modernity as the enabler of internationalisation of higher education and attainment of universalism (the paradigm of 'the one') 
(see Habermas 1997). Rather, the article pursues the agenda of completing the incomplete decolonisation so as to attain ecologies of knowledges and pluriversality. A decolonial internationalisation of higher education is posited as one predicated on a recognition of the diverse ways through which different people view and make sense of the world (the paradigm of pluralism/globalectics/pluriversality) (see Ngugi wa Thiong'o 2012, Santos 2014, Escobar 2018, Reiter 2018). The article is conceptual in its orientation. It questions a particular idea of 'the international' in its global bourgeoisneoliberal-capitalist articulation and posits a decolonisation of the internationalisation of higher education as a process which has the potential to subvert the long-standing modernist mono-culture of education, resilient Eurocentric epistemological fundamentalism (with its internal critiques which have failed to result in de-Europeanisation), and asymmetrical power dynamics so as to enable a non-colonial internationalisation of higher education.

Throughout the article 'the international', 'the global', and 'the universal' are subjected to decolonial critique and are never taken for granted, as is the case with neoliberal-inspired motivations for internationalisation of higher education. This is necessary because a colonially driven internationalisation of higher education is always underwritten by capitalist thinking without questioning the hierarchisation of knowledge and knowledge-generators which subverts the very ethos of non-hierarchical and decolonial internationalism.

In the conventional neoliberal capitalist-driven internationalisation of higher education worldwide, which is well captured by Isaac A. Kamola in Making the World Global: U.S. Universities and the Production of the Global Imaginary (2019) in terms of 'global networked university'; there is a general emphasis on labour needs for a globalised and liberalising economy, development of knowledge societies, leveraging on new information and communication technologies, and extracting profits from massification of higher education. The example given is that of New York University (NYU) under the presidency of John Sexton (2002-15), which has rebranded itself from being 'in and of the city' into being 'in and of the world' in its pursuit of markets and profits in such places as the Arab Emirates and China (Kamola 2019: 171). This is why even the definition of internationalisation of higher education is very instrumental and devoid of epistemic and ideological thought (see, for example, the widely cited definition from Jane Knight - the 'process of integrating an international, intercultural or global dimension into the purpose, functions or delivery of postsecondary education' (Knight 2003: 2, 2005: 13)).

Market fundamentalism is the core driver and this is why Kamola (2019: 171) posited that 'The reproduction of a highly market-oriented vision of a transcendental global university - one imagined as existing outside political constraints and market demands, and for the betterment of all humanity — forecloses the spaces from which 
to appreciate universities as worldly institutions.' What is often not taken into account are such factors as 'coloniality of knowledge' (how Eurocentric knowledge invaded the rest of the world's epistemic universes); exhaustion of existing modern knowledge and concomitant epistemic crisis; cognitive injustices and the need for cognitive justice; as well as possibilities of re-worlding from the Global South, for instance, and the resurgence and insurgence of 'epistemologies of the South' as necessary forces and factors in the drive for a decolonial internationalisation of higher education (see Chabal 2012, Comaroff \& Comaroff 2012, Santos 2014, 2018, Ndlovu-Gatsheni 2018, Santos \& Meneses 2020).

The Rhodes Must Fall movements, that began in South Africa in 2015 and quickly gained wider embracement, successfully turned universities into sites of struggles over the very idea and mission of the university in the present conjuncture. Consequently, the imperatives of internationalisation predicated on capital accumulation locked horns with demands for cognitive justice and epistemic freedom (see Santos 2014, 2017, Ndlovu-Gatsheni 2018). This is why it is necessary to begin by framing issues from a decolonial vantage point with its potential to critique conventional notions of internationalisation of higher education.

\section{Framing issues from a decolonial vantage point}

The outbreak of Coronavirus (COVID-19) in early 2020 and its fast spread across the world reinforced, in a rather cruel way, the realities of planetary human entanglements (the South in the North and the North in the South enabled by increased migrations) and the need for relevant transnational knowledge and education capable of helping humanity to deal with such challenges as this pandemic. At the core of these increased planetary human entanglements should have been transnational convergence of ecologies of knowledges and the emergence of pluriversities rather than universities as sites of knowledge generation, cultivation, and distribution. The reality on the ground, however, has been fast movement of capital and to some extent labour without a noticeable change in the constitution of knowledge concomitant with a planetary-entangled and globalised world. National universities as gifts of nationalisms of the 19th and 20th centuries have remained as monuments within a globalised world and are struggling to generate transnational knowledge and education free from coloniality: that is, knowledge and education from Europe and North America are being globalised while that of the Global South is being pushed to the margins.

This is why one of the key demands of decolonisation of knowledge and education is de-provincialisation, that is, de-marginalisation of the marginalised knowledges of the Global South, bringing them into the academy. The Global South is invoked here 
not as a geography but as site of knowledge production informed by struggles against Eurocentrism, colonialism, capitalism, and patriarchy (see Santos 2018). At the centre of these struggles are the agendas of de-universalisation/re-provincialisation, that is, confronting the centred-ness and overrepresentation of Europe and North America in knowledge production and dissemination that dates back to the time of colonial encounters and colonial conquests. As put by Boaventura de Sousa Santos (2018), what is envisioned is an opened space for the emergence of ecologies of knowledges and pluriversities (universities that take seriously particularities and pluralities of human existence, including multiplicity of languages) (see Santos 2017, NdlovuGatsheni 2018). As posited by Hamid Dabashi (2019), in knowledge and education there is overrepresentation of Europe:

Because of Europe we have lost the worlds we knew as our own. Because of Europe we yearn to retrieve the worlds of our own. And because of Europe we oscillate between the world Europe has enabled and the world we wish to enable after-Europe. Yes, Europe means imperialism, colonialism, militarism, conquest, and racism. Yes, Europe means science, technology, art, architecture, literature, and poetry, all concomitant with those nasty trajectories. (1)

Dabashi (2019: 3) made a profound intervention to the necessity of thinking beyond Europe which is necessary even for the current drive for internationalisation of higher education in these powerful words: 'I am also trying to think the world beyond Europe, after Europe, not against Europe, but despite Europe.' Euromodernity gave the Global South modern Westernised universities but the current reality of increased planetary human entanglements requires pluriversities. Pluriversities are accommodative of ecologies of knowledges and anchored on a mosaic epistemology/epistemology of conviviality (Santos 2007, Nyamnjoh 2017, Connell 2018). At the centre of successfully internationalised higher education has to be pluriversities and ecologies of knowledges confronting and subverting long-standing racial hierarchies, gender hierarchies, and class hierarchies for the purposes of re-membering/re-humanising people and the production of relevant knowledge and just societies (Ngugi wa Thiong'o 2009a, 2009b, Santos 2017, Ndlovu-Gatsheni 2018, 2020).

How the long-standing European and North American self-positioning not only as the sole teachers of the world and the relegation of the rest of the world to the status of pupils but also as the only sites of rationality and reason continue to subvert the possibilities of emergence of pluriversities has to be subjected to consistent critique if internationalisation of higher education is to be freed from accusations of cognitive, cultural, and even technological imperialism. Europe and North America's teachings were packaged into many bags: namely, progress and salvation, civilisation and enlightenment, modernity and modernisation, development and emancipation, colonialism and pacification. What made this possible was the dawn of Euromodernity 
in the first instance. Euromodernity names one of the dominant frames of social and political thought underpinned by 'two fundamental assumptions: rupture and difference' (Bhambra 2007: 1). The 'rupture' enabled the colonisation of time in which Europe and later North America claimed the space of being 'modern' (present) while relegating the rest of the world to 'pre-modern' (past). The paradigm of 'difference' made Europe claim being human itself for themselves, pushing the rest of the human species into sub-humanity and at times non-humanity (Mignolo 2000, 2011, Bhambra 2007, Maldonado-Torres 2007, Santos 2007, Ndlovu-Gatsheni 2013a, 2013b, 2018, 2020, Grosfoguel 2019).

It is these developments which are constitutive of what James Blaut (1993) termed the 'colonizer's model of the world' where Europe conceived of itself as the centre of the world and the rest of the world as 'empty' not only of people but of knowledge and education (see also Tibebu 2011). What is apparent is that Europe and North America managed to assume the position of teachers of the world after committing what Ramón Grosfoguel (2013) termed the 'four genocides/epistemicides of the long 16th century'. The first was the military conquest of Al-Andalus and the burning of the library of Cordoba in the 15th century. The second was the genocide/epistemicide against indigenous peoples of the Americas that commenced in 1492. The third was the kidnapping and reduction of African people into slaves who were shipped across the Atlantic Ocean to work in the plantations and mines. The fourth was the 'conquest and genocide of women in European lands who transmitted Indo-European knowledge from generation to generation' which began with their accusation as witches resulting in being burnt alive (see Grosfoguel 2013: 85; see also Stardust 2007, Suárez-Krabbe 2016).

Therefore, one can posit that, philosophically, the construction of European superiority in the domains of rationality, reason, knowledge, and education manifested itself in the Cartesian dictum-cogito ergo sum (I think, therefore I am) and was justified in the philosophy of Georg Wilhelm Friedrich Hegel (1770-1831) the 'apostle of modernity', particularly from his Lectures on the Philosophy of World History where he posited that:

In Africa proper, man has not progressed beyond a merely sensuous existence, and has found it absolutely impossible to develop any further. Physically, he exhibits great muscular strength, which enables him to perform arduous labours; and his temperament is characterised by good-naturalness, which is coupled, however, with completely unfeeling cruelty. Asia is the land of antithesis, division and expansion, just as Africa is the land of concentration. One pole of the antithesis is that of ethical life, the universal rational essence which remains solid and substantial; the other is exact spiritual opposite, that of egotism, infinite desires, and boundless expansion of freedom. Europe is the land of spiritual unity, of retreat from boundless freedom into the particular, of control of the immediate and elevation of the particular to the universal, and of the descent of the spirit into itself (Hegel 1998: 172-3). 
The result was epistemic racism that was well captured by Walter Mignolo (2010: xxxiii) in which 'Africans have experience, Europeans have philosophy, Native Americans have wisdom, Anglo-Americans have science, the Third World has cultures, the first world has science and philosophy.' This reasoning is constitutive of Eurocentrism as a cultural expression of Euro-North American-centric modernity (see Amin 2009). In short, the Europe that was constructed is that of a teacher of the world because Europe becomes the site of the triumph of the scientific spirit, rationality, practical efficiency, democracy, human rights, equality, and social justice (Headly 2008, Amin 2009). Jack Goody (1996) depicted these claims as amounting to the "theft of history' (stealing human history itself by Europe).

Decolonisation confronts these Eurocentric ideas and rationalities which not only enabled physical colonialism but cognitive/metaphysical colonialism as well. The cognitive/metaphysical colonialism (empires of the mind) was delivered through invasion of the mental universe of its targets (see Fanon 1968, Nandy 1981, Ngugi wa Thiong'o 1986, Chinweizu 1987, Ndlovu-Gatsheni 2018, Santos 2018, Gildea 2019). However, as noted by Aime Cesaire (2000), colonisation of the minds was never the best method of placing different civilisations and different people into positive contact to produce genuine internationalism. Cesaire made the following observation:

I admit that it is good thing to place different civilizations in contact with each other; that it is an excellent thing to blend different worlds; that whatever its own particular genius may be, a civilization that withdraws into itself atrophies; that for civilization, exchange is oxygen [...]. But then I ask the following question: has colonization really placed civilizations in contact? Or, if you prefer, of all the ways of establishing contact, was it the best? I answer no. And I say that between colonization and civilization there is an infinite distance. (11-12)

Cesaire like many decolonial theorists is for internationalisation born out of blending of civilisations and human encounters, but what he is against is colonisation as a method of delivering internationalisation (blending of civilisation and human entanglements). It was also Cesaire (84) who offered a nuanced decolonial insight into critical thinking and deeper understanding of internationalisation:

Provincialization? Absolutely not. I am not going to confine myself to some narrow particularism. But nor do I intend to lose myself in a disembodied universalism. There are two ways to lose one-self: through walled-in segregation in the particular, or through dissolution into the 'universal.' My idea of the universal is that of a universal rich with all that is particular, rich with all particulars, the deepening and coexistence of all particulars.

This intervention by Cesaire informs the decolonial approach to internationalisation of higher education and knowledge. The decolonial approach is deeply aware of the other practical challenges in the drive towards internationalisation of higher education 
and knowledge. These challenges were clearly distilled and articulated by Adebayo Olukoshi and Paul Tiyambe Zeleza (2004: 3) from the vantage point of African universities in these revealing terms:

How to balance autonomy and viability, expansion and excellence, equity and efficiency, access and quality, authority and accountability, representation and responsibility, diversification and differentiation, internationalization and indigenization, global presence/visibility and local anchorage, academic freedom and professional ethics, privatization and the public purpose, teaching and research, community service/social responsibility and consultancy, diversity and uniformity, the preservation of local knowledge systems and the adoption of global knowledge systems, knowledge production and knowledge dissemination, the knowledge economy and the knowledge society?

It would seem that at the centre of internationalisation of higher education there is a need to open up to a mode of balancing of imperatives cascading from diverse constituencies and different stakeholders. A pluriversity would emerge as a synthesis of diverse imperatives. It is, therefore, important to delve deeper into how epistemology frames ontology and how the present problematic 'international' was invented.

\section{The primacy of knowledge, education, and creation of 'the international'}

The primacy of knowledge as a creator of reality well expressed by Walter D. Mignolo \& Cathrine E. Walsh (2018: 135) when they argued that: 'Ontology is made of epistemology. That is, ontology is an epistemic concept; it is not inscribed in the entities the grammatical nouns name.' The importance of this argument is that it not only resolves the long-standing 'ontology-epistemology' conundrum which always degenerated into 'egg-chicken' debates but it also enables a new take on the relationship of knowledge to systems and institutions. Building on this argument it becomes clear that 'the international' is an epistemic creation as it is a political one (see Ndlovu-Gatsheni 2018, 2020).

By the same token, such sectors of modern life as politics, society, and economy are also epistemic creations. Santos (2018: 27) also emphasised the fact that knowledge creates the world: 'On the one hand, social scientific knowledge invented much of what it described as existing; such an invention became part of social reality as it got embedded in ways people behave and perceive social life.' The important question which arises is that of which knowledge created the present 'international' to which higher education has to be panel-beaten to fit. Of course, the making of the modern 'international' has always been a contested terrain from within and from without, pitting the hegemonic/colonial knowledge of the European bourgeois (Eurocentrism, 
liberalism, and neoliberalism) against Marxist leftist knowledge as well as feminist, black radical traditions, indigenous and endogenous, decolonial and postcolonial informed knowledges, for example (see Robinson 1983, Hountondji, 1997, 2002, Oyewumi 1997, Smith 1999, Amin 2011, Chilisa 2012, Shilliam 2015, Imlay 2018, Motta 2018, Ndlovu-Gatsheni 2018, 2020, Quan 2019).

What also emerges poignantly from this thinking about knowledge is that, before one jumps to techniques of how to internationalise higher education, there is a deeper question of which epistemology would anchor an internationalised higher education because, as put forward by Sandra Harding (2018: 39), there is indeed 'one planet' but with 'many sciences'. Harding (2018: 54) explores the problems of a unification of sciences through the methodology of 'add diversity and stir' (for instance, adding intellectual and academic works produced from the Global South into an existing curriculum) as 'insufficient to eliminate Eurocentric sciences and their philosophies' founded on racism, patriarchy, colonialism, and capitalism. Is internationalisation of higher education a process of submitting institutions of the rest of the world to the 'European game' that was named by Frantz Fanon (1968)?

Leading scholars of international relations, such as Amitav Acharya \& Barry Buzan (2019), have noted that the Global South has always been sidelined in modern conceptions of 'the international'. Colonies were excluded because the term 'international' was a reference to legal transactions and relationships between sovereigns. Such discrimination based on race and power led such African scholars as Ibekwe Chinweizu (1975) to write about 'the west' and 'the rest of us'. Perhaps the key point to be made here is that, if colonialism was fundamentally about conquest and ownership of the earth by colonial conquerors since the 15th century, then the decolonisation of the 21st century should be about claiming the earth as a home for everyone (Mbembe 2021). Perhaps, this is why decolonisation as defined by Adom Getachew (2019) has always been a re-worlding and re-making of the world so as to transcend legal, political, economic, epistemic, and economic hierarchies, and to create an egalitarian post-imperial, post-colonial, and post-racial world.

Taking into account all these issues, the key point is that internationalisation of higher education cannot be a simplistic process of integration of 'the rest of us' into the 'European game'. Without the de-homogenisation of the stranglehold of Eurocentric epistemological orders, internationalisation of higher education remains problematic because it will continue the tethering of 'the rest of us' to am asymmetrical modern world system and its shifting global orders. What appears as a 'postWestern/European world' which pretends to be post-colonial and post-racial is not yet free from global coloniality, that is, the consequences of the 'transhistoric expansion of colonial domination and the perpetuation of its effects in contemporary times' (Morana et al. 2008: 2). Mbembe (2019: 20) added other elements to what he termed 
'colonization of the 21st century': 'It is about extraction, capture, the cult of data, the commodification of human capacity for thought, and the dismissal of critical reason in favour of programming.' This takes us to locus of enunciation and global economy knowledges as necessary anchors of internationalised higher education.

\section{Locus of enunciation, global economy of knowledge, and international higher education}

The Eurocentric idea of a universal, disembodied, truthful, and decontextualised knowledge is today grappling with the decolonial concept of a locus of enunciation which posits that there is no knowledge and education which is free from racial, ethnic, gender, sexual, class, and other vectors of human identities and positionalities (Grosfoguel 2007). If this is the case, the question which arises is how internationalised higher education will deal with these issues. The Eurocentric idea of a universal knowledge where local and geography does not matter has given ammunition to the neoliberal notion of global economy of knowledge. Consequently, a 'global turn' and an idea of a 'global university' is being pushed forward by neoliberal globalists (see Kamola 2019). The decolonial concept of a locus of enunciation drives the insurgent and resurgent struggles of epistemological decolonisation of the 21st century led by such movements as the Rhodes Must Fall and Black Lives Matter, which are critical of notions of universities existing as unanchored institutional floating outside the orbit of the modern world (Kamola 2018, Ndlovu-Gatsheni 2018). Perhaps it was these debates and contestations which led Kamola (2019:9) to argue that:

Unable to exit the earth's orbit, colleges and universities are always and already worldly institutions, grounded in long histories and inscribed within vast economic, social, political, and cultural structures and practices. Despite being located within vast overdetermined social relationships, those students, scholars, and administrators inhabiting the world of higher education often imagine universities as extraworldly spaces from which to orbit - and gaze down upon - the world below. In claiming to reflect upon the world, seeing it as it actually is, the university often fades from the foreground, cropped out of the imaginary. In this process, colleges and universities increasingly are perceived as ivory towers located above and outside the world. In reality, however, there is no outside from which to view the world as a single thing, global or otherwise. A university is not a capsule floating outside the world's orbit. As such, academic knowledge is never merely a snapshot of the world outside itself.

The point is that higher education is not only a site of contestation of ideas; it is part of and reflective of the material world. Thus, knowledge and education are generated, cultivated, and reproduced within a material world of people. Perhaps it was this 
recognition which led Ngugi wa Thiong'o (1986: 87) to define epistemological decolonisation as the 'quest for relevance' and 'the search for a liberating perspective within which to see ourselves clearly in relationship to ourselves and to other selves in the universe'. He emphasised that 'how we view ourselves' 'is very much dependent on where we stand in relationship to imperialism in its colonial and neo-colonial stages; that if we are to do anything about our individual and collective being today, then we have to coldly and consciously look at what imperialism has been doing to us and to our view of ourselves in the universe' (88). He proceeded to define locus of enunciation in these convincing words: 'How we see a thing - even with our eyes - is very much dependent on where we stand in relationship to it' (88). In decolonial thought, Europe is a major and dominant locus of enunciation of modern knowledge and education not as geography but as epistemic and linguistic formation. The best definition of West (of which Europe is a major part) comes from Mignolo (2010: xxv):

What constitutes the West more than geography is a linguistic family, a belief system and an epistemology. It is constituted by six modern European and imperial languages: Italian, Spanish and Portuguese, which were dominant during the Renaissance, and English, French and German, which have been dominant since the Enlightenment.

Major theories and models come from Europe. As such it cannot hide its locus of enunciation and pretend that its particularity is universality. The Latin American decolonial theorists also emphasised the importance of a locus of enunciation. Mignolo $(1992,1993)$ defined a locus of enunciation as the disciplinary, geo-cultural, and ideological space from which discourses of power and resistance are elaborated. Ramón Grosfoguel (2007:213) reinforced this argument this way: 'Nobody escapes the class, sexual, gender, spiritual, linguistic, geographical, and racial hierarchies of the modern/colonial/capitalist/patriarchal world-system'. At the centre of locus of enunciation is 'the geo-political and body-political location of the subject that speaks' (Grosfoguel 2007: 213).

However, there are critics of the idea of a locus of enunciation. These critics seem to have been enchanted by hegemonic neoliberal globalisation. In the first place, they critique the very notion of coloniality of knowledge, arguing that 'knowledge has been propagated, contested, nullified, subverted and transformed across more than three centuries stretching from the precolonial society to post-apartheid governance' (Jansen 2019: 5). The critique is well expressed by Fran Collyer et al. (2019: 1): 'there is a widespread idea that we live in a knowledge society, an information society, or a technological society. Yet in most fields of research, there is an idea that the disciplines we work in, and the concepts we work with, do not come from any particular place in that society. They are just in the air, so to speak.' 
The second line of critique to then is to try to dismiss decolonisation of knowledge initiatives as hostage to archaic world systems and dependency theories which were relevant in the 1960s and 1970s but are no longer making sense in the present (Jansen 2019: 5). At least Collyer et al. (2019: 11) attributed this argument to 'some Northern scholarship about globalization' and admitted that 'the facts of gross world economic inequalities, disproportionate military and state power, the transnational corporate economy, and the hierarchical practices of knowledge institutions, remain' (see also Collyer 2014). In the third place, the critics of decolonisation even distort its logics to the extent of saying it posits an idea of an 'all-powerful (and epistemologically homogenous) West imposing its will on vulnerable, weak and powerless colonies or former colonies' (Jansen 2019: 5). The reality is that decolonial scholarship is opposed to all forms of fundamentalisms and has documented various forms of contestations and resistances to all impositions from Europe from as far back as the slave revolts in the diaspora. This is evident from decolonial scholarship's advancement of 'endogenous knowledge', 'theory from the South', and 'epistemologies of the South' (see Hountondji 1997, Mignolo 2000, Comaroff \& Comaroff 2012, Santos 2018). So there is no advancement of victimhood in decolonisation scholarship. It is a combative scholarship.

In the fourth instance, those who push for decolonisation of knowledge are heavily criticised for 'misrepresentation of Western knowledge as unitary when, in fact, the West itself has experienced considerable epistemological turmoil over more than a century that belies the description of European science as positivist, universal, and exclusionary' (Jansen 2019: 10). What the critics of decolonisation believe is clearly posited by Jonathan Jansen (2019: 5):

A sense of the world in which knowledge is increasingly co-produced through powerful partnerships in those two parts of the world system is a pervasive reality that defies an earlier but persistent notion that theory is developed in the West and applied in Africa and other parts of the formerly colonized world.

This thinking is deliberately oblivious of the persistent problem of uneven intellectual and academic division of labour and the concomitant intellectual and academic 'imperialism' and 'extraversion' on the one hand, and the consequent intellectual and academic dependencies on the other (see Ake 1979, Hountondji 1990, 1997, 2002, Ndlovu-Gatsheni 2018, 2020). What is very worrying about Jansen's critique of decolonisation is that he does not attribute it to any work of decolonial scholars or any identifiable decolonial scholar. They seem to come from his head. What he does is to apportion his misunderstandings to decolonial scholarship in general and then quarrel with them. 
One wonders if Jansen ever read any serious decolonial scholarship beyond journalistic articles because he does not cite any of this rich archive at all while pretending to be grappling with its limits. This is why he simplistically dismisses the concept of locus of enunciation as 'narcissism of identity politics' (Jansen 2019: 6). Worse still, the contributors to Jansen's edited book are not saying what he is saying in the introduction. So the introduction has nothing to do with the content of the book. Serious decolonial scholarship is fully cognisant of what Immanuel Wallerstein (1997: 103) termed 'anti-Eurocentric-Eurocentrism' masquerading as 'epistemological turmoil' (a term used by Jansen) within dominant Western-centric knowledge. Of course, paradigmatic changes in Western knowledge are well documented by Thomas S. Kuhn (1962), but they do not amount to de-hierarchisation, de-Europeanisation and decolonisation of knowledge. The work of Amy Allen (2016) goes deeper into 'decolonizing the normative foundation of critical theory' which is informed by such Enlightenment norms as salvation, progress, civilisation, modernity, modernisation, development, and emancipation. The point is that criticality within Eurocentric knowledge has always been there and such critical social theory as Marxism emerged within, but it did not aim to dethrone the normative foundations. One is led to argue that some critics of decolonisation of knowledge have a very static understanding of colonisation itself. Perhaps this is why Mbembe (2019: 19) emphasised that:

We need to develop a broader understanding of 'colonization.' Knowledge systems worldwide are still underpinned by the logic of value extraction. In fact, knowledge as such is increasingly designed as the principal means of value extraction. Colonization is going on when we throw out of the window the role of critical reason and theoretical thinking, and we reduce knowledge to the mere collection of data, its analysis and its use by governments, military bureaucracies and corporations. Colonization is going on when we are surrounded by so-called smart devices that constantly watch us and record us harvesting vast quantities of data, or when activity is captured by sensors and cameras embedded within them.

But what is also missing from most of the critiques of decolonisation of knowledge and education is an understanding that it is not about insulation, 'ghettoisation', and nativism. Rather decolonisation is opposed to all forms of fundamentalisms beginning with Eurocentric fundamentalism. In this context, locus of enunciation demands recognition of diverse ways of knowing for which internationalised higher education has to be anchored. Again Mbembe (2019: 15) explained it better:

I am talking about expanding the archive, not excising it. For this to happen, it must be clear to all that European archive alone can no longer account for the complexities, both of history, of the present, and of the future of our human and other-than- 
human world. What we all inherit are the archives of the world at large. [...]. I am in favour of expanding the archive, reading the different archives of the world critically, each with and against the other. There can't be any other meaning to a planetary curriculum.

A decolonial international higher education has to be underpinned by consistent and systematic transcultural translation, mosaic/convivial epistemology, and ecologies of knowledges as ingredients of a planetary curriculum.

\section{Intercultural translation, mosaic/convivial epistemology, and ecologies of knowledges}

Uncertainties of knowledge as documented by Wallerstein (2004) and the exhaustion of Northern epistemologies as detailed by Santos $(2014,2018)$ offer an opportunity not only to reorganise the world of knowledge but also to embrace epistemologies of the South. This cannot happen unless the world takes seriously Jean Comaroff \& John L. Comaroff's (2012: 1) radical suggestion: 'But what if, and here is the idea in interrogative form, we invert that order of things? What if we subvert the epistemic scaffolding on which it is erected? What if we posit that, in the present moment, it is the global south that affords privileged insight into the workings of the world at large?' Such a radical unlearning and unthinking of some forms of thinking cannot be successful without investment in and commitment to intercultural translation, mosaic/ convivial epistemology, and ecologies of knowledges.

As noted by Cesaire (2000), colonialism was never the best mechanism to deliver intercultural translation mainly because it was a dismembering and dehumanising process. What colonialism created is problematic 'transcultural elites' (liminal subjects) in the colonies which it refused to fully accommodate and pushed into a 'juridical limbo' (see Mamdani 1996, Madlingozi 2018, Motta 2018). As such it was never its intention to bring diverse civilizations together and blend them together. At the core of intercultural translation is cognitive justice: that is, recognition of different ways of knowing by which diverse people across the globe view and interpret the world and provide meaning to their existence (see Santos 2014, 2018). Intercultural translation is a key enabler of non-colonial internationalisation of higher education because it accommodates and cultivates different knowledges anchored in different cultures. This is why Santos (2018: 32) provided motivation for it in these words: 'intercultural translation contributes to turning the world's epistemological and cultural diversity into na favourable, capacitating factor in furthering the articulation between struggles against capitalism, colonialism, and patriarchy.' Intercultural translation is a powerful decolonial tool enabling recognition of difference not as an obstacle to human 
conviviality but as a solid base to construct a pluriverse founded on 'degrowth, commoning, conviviality, and a variety of pragmatic transition initiatives' as well as 'relationality' and 'radical interdependence' (Escobar 2018: 4). Intercultural translation enables transcendence over epistemicides, culturecides, and linguicides as it re-members rather than dismembers (Ndlovu-Gatsheni 2018). Perhaps Raewyn Connell (2018: 22) was thinking of intercultural translation when she noted that: 'The problem is not a deficit from the periphery-it is a deficit of recognition and circulation.'

The fact that all human beings were born into valid and legitimate knowledge systems is the soul of intercultural translation and it links it very well with the concepts of mosaic epistemology as articulated by Connell (2018) and epistemology of conviviality as defined by Francis Nyamnjoh (2017) as well as that of ecologies of knowledges introduced by Santos (2007). Taken together these concepts help in transcending and indeed deleting the racist 'abyssal thinking' (paradigm of difference along the human line) founded on what William E. B. Du Bois (1903) termed the 'colour line' that created what Frantz Fanon (1968) termed the 'zone of being' and the 'zone of non-being' (see Du Bois 1903, Santos 2007, Grosfoguel 2019). Modern knowledge and education were heavily shaped by this 'abyssal thinking' to the extent that decolonisation has led to 'post-abyssal thinking' amenable to ecologies of knowledges and mosaic epistemology (Santos 2018, Santos \& Meneses 2020). Post-abyssal thinking confronts what Connell (2018: 30) termed 'the pyramidal model implicit in the mainstream economy of knowledge'. It was Connell (30) who introduced the concept of 'mosaic epistemology'. This is how she defined it:

Separate knowledge systems sit beside each other like tiles in a mosaic, each based on a specific culture or historical experience, and each having its own claims to validity. Mosaic epistemology offers a clear alternative to Northern hegemony and global inequality, replacing the priority of one knowledge system with respectful relations among many (30).

There can be no mosaic epistemology without ecologies of knowledges and vice versa. Mosaic epistemology has to be dynamic and interactive, always open to horizontal interactions and solidarities. At its core is the idea of 'mutual learning on a world scale' (Connell 2018: 31). This means that decolonial international higher education has to be informed by a deliberate shift from 'a Northern-centred global economy of knowledge with a pyramidal epistemology to a Southern-centre global economy of knowledge with a solidarity-based epistemology, where theory is produced and recognised at many sites, and thus brought closer to popular struggles and everyday life' (32).

The concept of mosaic epistemology resonates with what Nyamnjoh $(2017,2018)$ depicted as convivial scholarship and convivial epistemology. Nyamnjoh's (2018: 3) 
departure point is Africa where people are caught up 'betwixt and between exclusionary and prescriptive regimes of being and belonging'. This is how Nyamnjoh introduced and defined convivial scholarship:

A truly convivial scholarship is one which does not seek a priori to define and confine Africans into particular territories or geographies, particular racial and ethnic categories, particular classes, genders, generations, religions or whatever other identity marker is ideologically en vogue. Convivial scholarship confronts and humbles the challenge of over-prescription, over-standardization, over-routinization, and overprediction. It is critical and evidence-based; it challenges problematic labels, especially those that seek to unduly oversimplify the social realities of the people, places and spaces it seeks to understand and explain (2017: 5).

What Nyamnjoh (2018: 3) is advocating is an epistemology that 'sees the local in the global and the global in the local' and is underpinned by 'informed conversations, conscious of the hierarchies and power relations at play at both the micro- and macro-level of being and becoming'. At the core of epistemology is the fact of 'incompleteness' as opposed to colonial and imperialist 'delusions of grandeur' and completeness of being, and Nyamnjoh (2017: 5) concluded that: 'conviviality depicts diversity, tolerance, trust, equality, inclusiveness, cohabitation, coexistence, mutual accommodation, interaction, interdependence, getting along, generosity, hospitality, congeniality, festivity, civility and privileging peace over conflict, among other forms of sociality'. Thus, for a decolonial internationalisation of higher education, there must always be 'recognition' and 'reconciliation' after centuries of depredations of the paradigm of difference (Nyamnjoh 2017: 6, Ndlovu-Gatsheni 2018). All this is possible if framed by the ethos of pluriversity originating from decolonial struggles targeting racism, colonialism, capitalism, and patriarchy.

\section{Conclusion: Towards a globalectics for pluriversity}

There can be no international higher education without decolonisation and globalectics/pluriversity. In his Globalectics: Theory and the Politics of Knowing (2012: 8), Ngugi wa Thiong'o defined globalectics this way:

Globalectics is derived from the shape of the globe. On its surface, there is no centre; any point is equally a centre. As for the internal centre of the globe, all points on the surface are equidistant to it-like the spokes of a bicycle wheel that meet at the hub. Globalectics combines the global and the dialectical to describe a mutually affecting dialogue, or multi-logue, in the phenomena of nature and nurture in a global space that is rapidly transcending that of the artificially bounded, as nation and region. The global is that which human in spaceships or on the international space station 
see: the dialectical is the internal dynamics that they do not see. Globalectics embraces wholeness, interconnectedness, equality of potentiality of parts, tension, and motion. It is a way of thinking and relating to the world, particularly in the era of globalism and globalization.

In the knowledge domain globalectics cannot be realised without re-founding and re-purposing the university. Re-founding is the radical action of transforming the university into a pluriversity. Re-purposing is redefining the mission of the university away from its complicity in epistemicides and cognitive injustices into a committed and indeed activist institution of higher education which confronts its problematic past while creating futures founded on social justice and cognitive justice (see Santos 2017, 2018, Santos \& Meneses 2020). A decolonial internationalisation of higher education's horizon is to turn universities into pluriversities where 'polyphonic'/diverse voices cascading from ecologies of knowledges and encouraged by mosaic/convivial epistemology and consistent intercultural translation (learning across cultures without rejecting their locus of enunciation) to strive and flourish (Santos 2017: 377-9).

The current internationalisation of higher education informed by hegemonic neoliberal/capitalist/commercial globalisation taking the form of harmonisation of credits, funded staff exchanges, fee-paying student exchanges, exchange of sabbaticals, enrichment of the curriculum with the addition of foreign languages and new materials from scholars from other places, the enrolment of foreign fee-paying students, establishment of offshore campuses, occasional partnerships in research, occasional collaboration in planning and hosting international conferences, and obsession with university rakings; do not amount to globalectics and pluriversity. These actions are mere responses to academic capitalism and university imperialism and they follow the logics of academic and intellectual structural adjustments to the dictates of market fundamentalisms.

This article is not opposed to the internationalisation of higher education. It is critical of internationalisation that is not founded on epistemological decolonisation and its logics of a locus of enunciation, intercultural translation, ecologies of knowledges, and mosaic/convivial epistemology. These logics are at the core of changing the very philosophy of higher education and the very idea of the university, leading to de-nationalising and un-walling of the university so as to open it up for transnational flows of knowledge and ecologies of community knowledge and formal knowledge. It is opposed to internationalisation that is not founded on rethinking and even unthinking thinking itself about knowledge and education so as to set afoot a pluriversity (see Wallerstein 1999). In decolonial terms: 'The task of rethinking thinking is therefore precisely this: to recognize the cultural asphyxiation of those numerous "others" that has been the norm, and work to bring other categories of self-definition, of dreaming, of acting, of loving, of living into the 
commons as a matter of universal concern' (Hoppers \& Richards 2012: 8). In this context, internationalisation of higher education cannot be a technical and procedural process, it has to be a liberatory and rehumanising project engaging with colonialism and dislocating it.

\section{References}

Acharya, A. \& Buzan, B. (2019), The Making of the Global International Relations: Origins and Evolution of IR at its Centenary (Cambridge, Cambridge University Press). https://doi.org/10.1017/9781108647670

Ake, C. (1979), Social Science as Imperialism: The Theory of Political Developmen. (Ibadan, Ibadan University Press).

Allen, A. (2016), The End of Progress: Decolonizing the Normative Foundation of Critical Theory (New York, Columbia University Press). https://doi.org/10.7312/alle17324

Amin, S. (2009), Eurocentrism: Modernity, Religion, and Democracy: A Critique of Eurocentrism and Culturalism, 2nd edn (New York, Monthly Review Press).

Amin, S. (2011), Global History: A View from the South (Cape Town, Pambazuka Press).

Bhambra, G.K. (2007), Rethinking Modernity: Postcolonialism and the Sociological Imagination (London, Palgrave Macmillan). https://doi.org/10.1057/9780230206410_3

Blaut, J.M. (1993), The Colonizer's Model of the World: Geographical and Eurocentric History (New York, The Guilford Press).

Cesaire, A. (2000. Discourse on Colonialism (New York, Monthly Review Press).

Chabal, P. (2012), The End of Conceit: Western Rationality After Postcolonialism (London and New York, Zed Books). https://doi.org/10.5040/9781350223097

Chilisa, B. (2012), Indigenous Research Methodologies (London, Sage).

Chinweizu, I. (1975), The West and the Rest of Us (New York: Random House).

Chinweizu, I. (1987), Decolonizing the African Mind (Lagos, Pero Press).

Collyer, F. (2014), 'Sociology, Sociologists, and Core-Periphery Reflections', Journal of Sociology, 50(3): 252-68. https://doi.org/10.1177/1440783312448687

Collyer, F., Connell, R., Mia, J. \& Morrell, R. (2019), Knowledge and Global Power: Making New Sciences in the South (Johannesburg, Wits University Press).

Comaroff, J. \& Comaroff, J.L. (2012), Theory From the South Or, How Euro-America Is Evolving Toward Africa (Boulder, CO, and London, Paradigm Publishers). https://doi.org/10.1080/00664677.2012.694169

Connell, R. (2018), 'Meeting at the Edge of Fear: Theory on a World Scale', in B. Reiter (ed.) Constructing the Pluriverse: The Politics of Knowledge (Durham, NC, and London, Duke University Press), $19-38$.

Dabashi, H. (2019), Europe and Its Shadows: Coloniality After Empire (London, Pluto Press). https://doi.org/10.2307/j.ctvr0qtvb

Du Bois, W.E.B. (1903), The Souls of Black Folk (New York, Dover Publications).

Escobar, A. (2018), Designs for the Pluriverse: Radical Interdependence, Autonomy, and the Making of Worlds (Durham, NC, and London, Duke University Press). https://doi.org/10.1215/9780822371816

Fanon, F. (1968), The Wretched of the Earth (New York, Groove Press).

Getachew, A. (2019), Worldmaking after Empire: The Rise and Fall of Self-determination (Princeton, NJ, and Oxford, Princeton University Press). https://doi.org/10.2307/j.ctv3znwvg 
Gildea, R. (2019), Empires of the Mind: The Colonial Past and the Politics of the Present (Cambridge, Cambridge University Press). https://doi.org/10.1017/9781316671702

Goody, J. (1996), The Theft of History (Cambridge, Cambridge University Press).

Grosfoguel, R. (2007), 'The Epistemic Decolonial Turn: Beyond Political-economy Paradigms', Cultural Studies, 21(2-3): 203-26. https://doi.org/10.1080/09502380601162514

Grosfoguel, R. (2013), 'The Structure of Knowledge in Westernized Universities: Epistemic Racism/ Sexism and the Four Genocides/Epistemicides of the Long 16th Century', Human Architecture: Journal of the Sociology of Self-Knowledge, 11(1): 73-90.

Grosfoguel, R. (2019), 'What is Racism? Zone of Being and Zone of Non-being in the Work of Frantz Fanon and Boaventura de Sousa Santos', in J. Cupples and R. Grosfoguel (eds.) Unsettling Eurocentrism in the Westernized University (London and New York, Routledge), 264-73. https://doi.org/10.4324/9781315162126-18

Habermas, J. (1997), 'Modernity: A Unfinished Project', in M. P. d'Entreves \& S. Ben-Habib (eds) Habermas and the Unfinished Project of Modernity (Cambridge, MA, MIT Press), 1-38.

Harding, S. (2018), 'One Planet, Many Sciences', in B. Reiter (ed.) Constructing the Pluriverse: The Geopolitics of Knowledge (Durham, NC, and London, Duke University Press), 39-62. https://doi.org/10.1215/9781478002017-003

Headly, J.H. (2008), The Europeanization of the World: On the Origins of Human Rights and Democracy (Princeton, NJ, Princeton University Press).

Hegel, G.W.F. (1998), Lectures on the Philosophy of World History: Introduction: Reason in History, trans. D. Forbes (New York, Cambridge University Press).

Hoppers, C.O. \& Richards, H. (2012), Rethinking Thinking: Modernity's 'Other' and the Transformation of the University (Pretoria, UNISA Press).

Hountondji, P.J. (1990), 'Scientific Dependence in Africa Today', Research in African Literatures, 21(3): $5-15$.

Hountondji, P. (ed.) (1997), Endogenous Knowledge: Research Trails (Dakar, CODESRIA Book Series).

Hountondji, P.J. (2002), The Struggle for Meaning: Reflections on Philosophy, Culture, and Democracy in Africa (Athens, $\mathrm{OH}$, Centre for International Studies, University of Ohio).

Imlay, T.C. (2018), The Practice of Socialist Internationalism: European Socialists and International Politics, 1914-1960 (Oxford, Oxford University Press). https://doi.org/10.1093/oso/9780199641048.001.0001

Jansen, J.D. (2019), 'Making Sense of Decolonization in Universities', in J.D. Jansen (ed.) Decolonization in Universities: The Politics of Knowledge (Johannesburg, Wits University Press), 1-12.

Kamola, I.A. (2019), Making the World Global: U.S. Universities and the Production of the Global Imaginary (Durham, NC, and London, Duke University Press). https://doi.org/10.1093/oso/9780199641048.001.0001

Knight, J. (2003), 'Updated Internationalization Definition', International Higher Education, 33: 2-17.

Knight, J. (2005), 'An Internationalization Model: Responding to New Realities and Challenges', in H. de Wit, I. C. Jaramillo, J. Gacel-Avila \& J. Knight (eds) Higher Education in Latin America: The International Dimension (Washington, DC, The World Bank), 1-38.

Kuhn, T.A. (1962), The Structure of Scientific Revolutions (Chicago, Il, University of Chicago Press).

Madlingozi, T. (2018), 'Mayibuye iAfrica? Disjunctive Inclusions and Black Strivings for Constitution and Belonging in "South Africa", unpublished PhD thesis, School of Law, Birkbeck, University of London.

Maldonado-Torres, N. (2007), 'On the Coloniality of Being: Contributions to the Development of a Concept', Cultural Studies, 21(2-3): 240-70. https://doi.org/10.1093/oso/9780199641048.001.0001

Mamdani, M. (1996), Citizen and Subject: Contemporary Africa and the Legacy of Late Colonialism (Princeton, University of Princeton Press). 
Mbembe, A. (2019), 'Thoughts on the Planetary: An Interview with Achille Mbembe'. https://www.newframe.com/thoughts-on-the-planetary-an-interview-with-achille-mbe... [Accessed 4 November 2020]

Mbembe, A. (2021), Out of the Dark Night: Essays on Decolonization (Durham, NC, and London, Duke University Press).

Mignolo, W.D. (1992), 'On the Colonization of Amerindian Languages and Memories of Writing and the Discontinuity of the Classical Tradition', Society and History, 34(2): 301-30. https://doi.org/10.1017/S0010417500017709

Mignolo, W.D. (1993), 'Colonial and Postcolonial Discourse: Cultural Critique or Academic Colonialism?', Latin American Research Review, 28: 120-34.

Mignolo, W.D. (2000), Local Histories/Global Designs: Coloniality, Subaltern Knowledge and Border Thinking (Princeton, NJ, University of Princeton Press).

Mignolo, W.D. (2010), 'Foreword: Yes, We Can', in H. Dabashi Can Non-Europeans Think? (London and New York, Zed Books), viii-xlii.

Mignolo, W.D. (2011), The Darker Side of Western Modernity: Global Futures, Decolonial Options (Durham, NC, and London, Duke University Press). https://doi.org/10.2307/j.ctv125jqbw

Mignolo, W.D. \& Walsh, C.E. (2018), On Decoloniality: Concepts, Analytics, Praxis (Durham, NC, and London, Duke University Press). https://doi.org/10.1215/9780822371779

Morana, M., Dussel, E. \& Jauregui, C.A. (2008), 'Colonialism and Its Replicants', in M. Morana, E. Dussel \& C.A . Jauregui (eds) Coloniality at Large: Latin America and the Postcolonial Debate (Durham, NC, and London, Duke University Press), 1-20.

Motta, S.C. (2018), Liminal Subjects: Weaving (Our) Liberation (London and New York, Rowman and Littlefield International).

Nandy, A. (1981), The Intimate Enemy: Loss and Recovery of Self Under Colonialism (Oxford, Oxford University Press).

Ndlovu-Gatsheni, S.J. (2013a), Coloniality of Power in Postcolonial Africa: Myths of Decolonization (Dakar, CODESRIA Books).

Ndlovu-Gatsheni, S.J. (2013b), Empire, Global Coloniality and African Subjectivity (New York and Oxford, Berghahn Books).

Ndlovu-Gatsheni, S.J. (2018), Epistemic Freedom in Africa: Deprovincialization and Decolonization (London and New York, Routledge). https://doi.org/10.4324/9780429492204

Ndlovu-Gatsheni, S.J. (2020), Decolonization, Development and Knowledge in Africa: Turning Over A New Leaf (New York and London, Routledge). https://doi.org/10.4324/9781003030423

Ngugi wa Thiong'o (1986), Decolonizing the Mind: The Politics of Language in African Literature (Oxford, James Currey).

Ngugi wa Thiong'o (2009a), Something Torn and New: An African Renaissance (New York, Basic Civitas Books).

Ngugi wa Thiong'o (2009b), Re-membering Africa (Nairobi, Kampala, Dar es Salaam, East African Educational Publishers).

Ngugi wa Thiong'o (2012), Globalectics: Theory and the Politics of Knowing (New York, Columbia University Press).

Nyamnjoh, F.B. (2017), Drinking from the Cosmic Gourd: How Amos Tutuola Can Change Our Minds (Mankon, Bamenda, Langaa Research \& Publishing CIG). https://doi.org/10.2307/j.ctvh9vw76

Nyamnjoh, F. (2018), 'Thinking, Researching and Writing Africa: Insights from Nigeria's Tutuola'. https://thecoversation.com/thinking-researching-and-writing-africa-insights-from-nigerias-tutuo... [Accessed 4 December 2020)

Olukoshi, A. \& Zeleza, P.T. (2004), 'Introduction: The Struggle for African Universities and Knowledges', in P.T. Zeleza \& A. Olukoshi (eds) African Universities in the Twenty-first Century: Volume 1: Liberalization and Internationalization (Dakar, CODESRIA Book Series), 1-18. 
Oyewumi, O. (1997), The Invention of Women: Making an African Sense of Western Gender Discourses (Minneapolis, MN, and London, University of Minnesota Press).

Quan, H.T.L. (ed.) (2019), Cedric J. Robinson: On Racial Capitalism, Black Internationalism, and Cultures of Resistance (London, Pluto Press).

Reiter, B. (ed.) (2018), Constructing the Pluriverse: The Geopolitics of Knowledge (Durham, NC, and London, Duke University Press). https://doi.org/10.1215/9781478002017

Robinson, C.J. (1983), Black Marxism: The Making of the Black Radical Tradition (London, Zed Books).

Santos, B. de. S. (2007), 'Beyond Abyssal Thinking: From Global lines to Ecologies of Knowledges', Review, 30(1): 45-89.

Santos, B. de S. (2014), Epistemologies of the South: Justice Against Epistemicide (Boulder, CO, and London, Paradigm Publishers). https://doi.org/10.4324/9781315634876

Santos, B. de S. (2017), Decolonizing the University: The Challenge of Deep Cognitive Justice (Newcastle upon Tyne, Cambridge Scholars Publishing).

Santos, B. de S. (2018), The End of the Cognitive Empire: The Coming of Age of Epistemologies of the South (Durham, NC, and London, Duke University Press). https://doi.org/10.1215/9781478002000

Santos, B. de S. \& Meneses, M.P. (eds) (2020), Knowledges Born in the Struggle: Constructing the Epistemologies of the Global South (New York and London, Routledge). https://doi.org/10.4324/9780429344596

Shilliam, R. (2015), The Black Pacific: Anti-colonial Struggles and Oceanic Connections (London, Bloomsbury).

Smith, L.T. (1999), Decolonizing Methodologies: Research and Indigenous Peoples (London and New York, Zed Books).

Stardust, L. (2007), Burning Women: The European Witch Hunts, Enclosure and the Rise of Capitalism: Second Edition (London, Past Tense Publishers).

Suárez-Krabbe, J. (2016), Race, Rights and Rebels: Alternatives to Human Rights and Development from the Global South (London and New York, Rowman \& Littlefield International).

Tibebu, T. (2011), Hegel and the Third World: The Making of Eurocentrism in World History (New York, Syracuse University Press).

Wallerstein, I. (1997), 'Eurocentrism and Its Avatars: The Dilemma of Social Science', New Left Review, 266: 93-107. https://doi.org/10.1177/0038022919970102

Wallerstein, I. (1999), 'Introduction: Why Unthink', in I. Wallerstein (ed.) Unthinking Social Sciences: The Limits of Nineteenth Century Paradigms (Cambridge, Polity Press), 1-26.

Wallerstein, I. (2004), The Uncertainties of Knowledge (Philadelphia, PA, Temple University Press).

Zeleza, P.T. (2012), 'Internationalization in Higher Education: Opportunities and Challenges for Knowledge Project in the Global South', Keynote Address Delivered at the Vice-Chancellors Leadership Dialogue: Internationalization in Higher Education: Opportunities and Challenges for the Knowledge Project in the Global South organized by the Southern African Regional Universities Association (SARUA), International Association of Universities (IAU) and Eduardo Mondlane University, Maputo, Mozambique, 21-22 March.

\section{Note on the author}

Sabelo J. Ndlovu-Gatsheni is a historian and decolonial theorist. He is currently Professor and Chair of Epistemologies of the Global South with Emphasis on Africa at the University of Bayreuth in Germany; member of African Studies Cluster of Excellence at the University of Bayreuth; Professor Extraordinarius in the Department of Leadership and Transformation (DLT) in the Principal \& Vice-Chancellor's Office at the University of South Africa (UNISA); Professor Extraordinarius at the Centre 
for Gender and African Studies at the University of Free State (UFS) in South Africa; Honorary Professor in the School of Education (Education \& Development Studies) at the University of KwaZulu-Natal (UKZN) in South Africa; Visiting Research Fellow at the Johannesburg Institute for Advanced Study (JIAS) at the University of Johannesburg (UJ) in South Africa; Research Associate at the Department of Political Science at the University of Pretoria (UP) in South Africa; and Research Associate at The Ferguson Centre for African and Asian Studies at The Open University in the United Kingdom. Before this current position, Professor Ndlovu-Gatsheni worked as Research Professor and Director of Scholarship at the Department of Leadership and Transformation (DLT) in the Principal and Vice-Chancellor's Office at the University of South Africa (UNISA). He previously worked as Acting Executive Director of Change Management Unit (CMU) in the Vice-Chancellor's Office at the University of South Africa (UNISA) (January 2018-September 2019), Director of Scholarship at CMU (2016-17), founding Head of Archie Mafeje Research Institute for Applied Social Policy (AMRI) (2012-15). He is also the founder of the Africa Decolonial Research Network (ADERN) based in at the University of South Africa and is a member of the Academy of Science of South Africa (ASSAf). sjndlovugatsheni@gmail.com

To cite the article: Sabelo J. Ndlovu-Gatsheni (2021), 'Internationalisation of higher education for pluriversity: a decolonial reflection', Journal of the British Academy, 9(s1): 77-98.

DOI https://doi.org/10.5871/jba/009s1.077

Journal of the British Academy (ISSN 2052-7217) is published by

The British Academy, 10-11 Carlton House Terrace, London, SW1Y 5AH

www.thebritishacademy.ac.uk 